\title{
GRAPHIC ORGANIZER VERSUS SENTENCE COMBINING: DETERMINING A STRATEGY FOR TEXT WRITING
}

\author{
Hendi Hidayat \\ IAIN Syekh Nurjati Cirebon \\ hendihidayat@syekhnurjati.ac.id
}

\begin{abstract}
This study examines how students with high and low interest who were trained through graphic organizer differ significantly from those who were trained through sentence combining strategy in writing hortatory text. The subjects of the study were the eleventh grader students of MANU Buntet Pesantren Cirebon in the Academic Year of 2015/2016. The population consists of 315. Two of eight classes were selected as the sample of the research. The experiment was set up according to a pre-test and post-test for both experimental and control group. The writer used an experimental research with factorial design $2 \times 2$ as the research design by technique of multifactor analysis of variance (ANOVA). The findings of this study indicate that graphic organizer is more effective than the sentence combining strategy. It can be seen from the results of both scores in the experimental class that the scores of the post-test have significantly different comparing to the post-test scores in the control group. The writer also found that since learners generally have more background knowledge, graphic organizers bridge what learners already know with what they are learning.
\end{abstract}

Keywords: Graphic organizer, Sentence Combining, Interest, hortatory, experiment.

\section{BACKGROUND}

Realizing that the demand of English as an international means of communication as used in education and career grows rapidly in Indonesia, it is reasonable that our government places English as a crucial subject in our education system. The government has also made a lot of attempts to make the students successful in learning English. The books are prepared, the teachers are trained, and the teachinglearning process is monitored. However, in some cases, the students still have difficulties in learning English.

In the smaller scope of educational setting, i.e. at schools, most of examinations require students to use their writing skill. In short, students' success at school is also determined by their writing skills. Furthermore, it is commonly understood that good writing will foster good thinking and vice versa.

Writing presents a challenge; both writing in the mother tongue and the foreign language one. Nunan (1999) argued that the most difficult task to do in language learning is to produce a coherent, fluent, extended piece of writing, which is even more challenging for second language learners. In line with Nunan, Richard and Renandya (2002) realized that productive skills might be more difficult to be mastered than receptive skills. This due to the fact that the productive skill - particularly writing - is not just producing the product of writing, but it needs some cycles and process to produce the sophisticated product of writing. Furthermore, if just focus on the product, the EFL learners are only interested in the aim of a task and in the product. The process of writing is more complex; it includes various stages of drafting, reviewing, redrafting and writing (Tribble, 1997 cited in Harmer, 1999). 
This study examines two writing Strategies which are correlated with the process of writing in second language writing process. It has attempted that writing process is strategically, rhetorically and linguistically different from L1 writing process and novice L2 writers must be taught L2 writing strategy explicitly (Mu \& Carrington, 2007). Begin from the problem of writing, many researchers who investigated writing in different ways think that the various purposes of writing, its myriad contexts of use and the diverse backgrounds and needs of those wishing to learn it, all push the study of writing into wider frameworks of analysis and understanding (Hyland, 2009: 2).

The main reason why writing strategies was chosen, is because the writer wants to determine the appropriate strategy for learners in text writing. Tuzlukova et al. (2014) asserted that school and university writing curricula also need alignment with the emphasis on ideas' development, content knowledge, critical and creative thinking based on the collaborative efforts of the educators from both contexts.

In this study, the writer assumed that the writing strategy will support the EFL learners of their writing process. Hyland (2008) in approaching writing tasks, argues that writers are actually searching for solutions to a series of problems.

Hence, in line with the background above, the writer is interested to compare the use of graphic organizer and sentence combining strategy as students' writing strategy in composing hortatory exposition text. The study is primarily intended to know 1) how significant the effect of graphic organizer on students with high and low interest in writing hortatory exposition is, 2) how significant the effect of sentence combining strategy on students with high and low interest in writing hortatory exposition is, 3) how significant the difference between students with high and low interest who are trained by graphic organizer and sentence combining strategy in writing hortatory exposition is, and 4) how significant the interaction among writing achievement, strategy, and interest in writing hortatory exposition is.

In some studies, some researchers related their studies to writing strategies. As found in Trang and Hoa (2008), Alnufaie and Grenfell (2013), Tuzlukova et al. (2014) and Chen (2011). They focused on investigating writing strategies in some texts. Trang and Hoa (2008) investigated the problems of writing academic assignments of a particular Vietnamese ESL student studying at an Australian university. Similar study has been done by Tuzlukova et al. (2014) who investigated the problems faced by university language learners in Oman encounter when writing in English and of the strategies they follow to overcome these problems. Meanwhile, Alnufaie and Grenfell (2013) observed the instructional type of writing strategies used by EFL college students in Saudi Arabia. Chen (2011) similarly investigated English writing strategies of 132 Chinese, non-English major college students found that although the students used some writing strategies in the pre-writing stage, while-writing stage and revising stage.

However, there were some differences between the previous researches and this research. Hence, this research was still worth to be done. First, this study compares two writing strategies which are graphic organizer and sentence combining strategy. Second, this study examines the strategy on senior high school students in writing hortatory exposition. Third, the subject of the study were classified based on their interest in writing. The explanations of each keywords relate to the study are as it follows. 


\section{Graphic Organizer}

Graphic organizer can be defined as a conceptual communicative tool (Katayama et al., 2000) and a series of visual charts and tools used to represent and organize a student's knowledge or ideas. Graphic organizers are often used as part of the writing process to help students map out ideas, plots, character details and settings before beginning to write. Morin (2012) explains that graphic organizers can be applied both in reading and writing. In this case, the writer would like to explore organizers in reading. Graphic organizers can help student in comprehending difficult text. In this case, there are many types of graphic organizers for instance story mapping, Venn diagram, semantic map, concept mapping and so on.

On the other hand, Hartman (2002: 46) categorizes graphic organizers into some formats which are concept maps, flowcharts, sequence chains, Venn diagrams, and webs. Meanwhile, Broomley (1995) divides the types of graphic organizer into conceptual, Hierarchical, Cyclical, and Sequential. Below are the elaborations of graphic organizer adapted from Bromley et al. (1995): (1) conceptual, this type of graphic organizers includes a main concept or a central idea with supporting facts, evidence, or characteristics. It helps students show their learning or knowledge of a central idea, (2) hierarchical, this type of graphic organizers begin with a topic or concept and then include a number of ranks or levels below the topic and It is used when a student needs to break down broad concept into sub concepts, (3) cyclical, the cyclical organizer depicts a series of events without beginning or end. The formation is circular and continuous, and (4) sequential, it arranges events in chronological order. This type of organizers is helpful when events have a specific beginning and end. It is also appropriate for cause and effect, process-and-product and problemsolving text.

Here are the samples of graphic organizer:
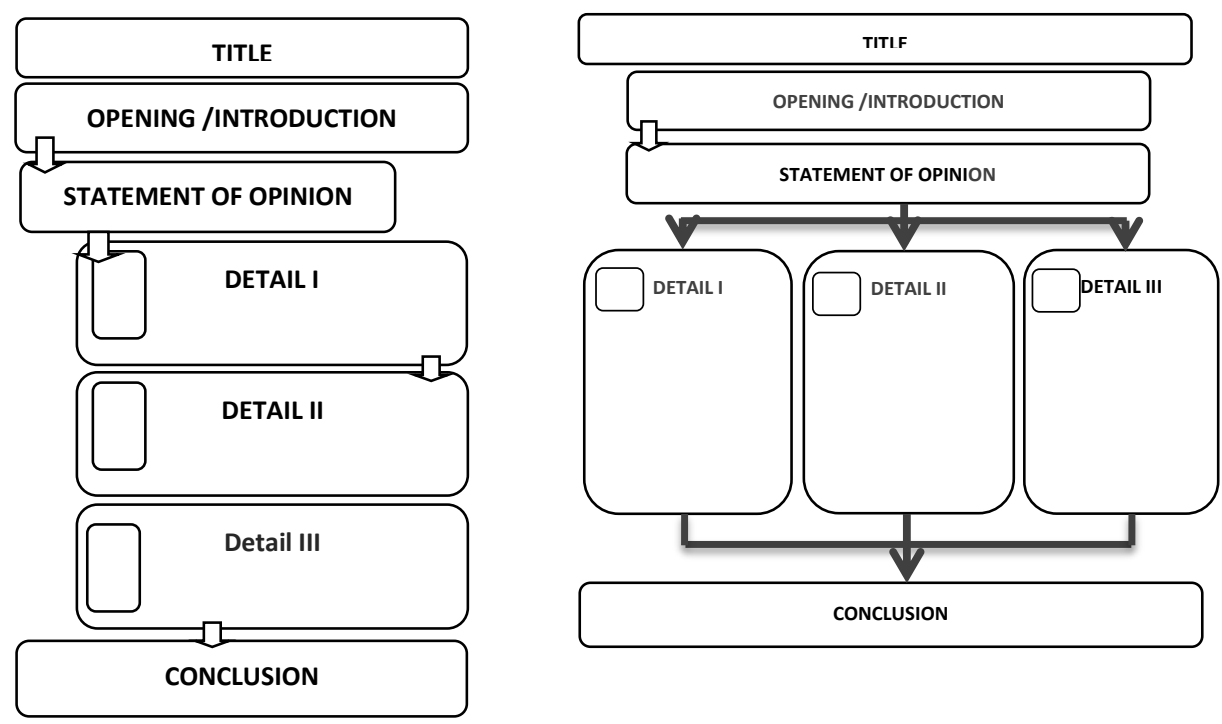

Figure 1 Samples of Graphic Organizer

Baxendell (2003) argued that there are three components for a successful graphic organizer: consistency, coherence, and creativity. Consistency is especially important for students since they benefit from routine and structure. Consistency allows the students to become familiar with the layout of the organizer, so that they may 
process the information without the added burden of processing format. Internalization and generalization of information is more likely to occur when the student is already comfortable with the layout of the relationships (Baxendell, 2003; Ellis \& Howard, 2005).

Coherence is also important aspect of GO. The purpose of the GO is to present the information in a fluid, understandable manner and to aid in the reduction of cognitive load. A coherent GO is not visually distracting, doesn't contain too much information, has clear labels, and is a visual representation of the hierarchy of concepts (Baxendell, 2003; Ellis \& Howard, 2005).

Besides, creativity in the use of GO is also important for engaging the students' learning. In this context, creativity does not refer to the stylistic choice of making the GO themselves, rather it refers to how the GO are implemented by the teacher (Baxendell, 2003). Students need to be actively included in creating the GO, bringing prior knowledge and discussion to develop the main ideas and details (Ellis, Farmer, \& Newman, 2005).

Some studies discussed some theories and conclusions regarding the implementation of graphic organizer as a strategy to assist students learning process. Barnett (2007) concludes that using a graphic organizer within Reading/Writing and Social Studies lessons is an effective way to enhance comprehension. The research showed significant improvement to almost all of the students over 3-week period when graphic organizers were used in reading and writing. Donahoo (2009) also finds that graphic organizers are useful thinking tools that allow students to organize information and allow students to see their thinking. In addition, Katayama et al. (2000) conclude that graphic organizer is computationally more efficient than outlines or texts and it engages students in learning, resulting in encoding benefits.

In Indonesia, the use of graphic organizer in writing was conducted by Mulyaningsih (2010) with the fifth grade elementary school as the subject of the research and narrative as the text focus. In her research, the use of graphic organizer proved to produce some improvements in the students' writing performance. It can be seen from the writing output in terms of content, organization, vocabulary, coherence and the cohesiveness. It also helps the student as a note guide in presenting their writing in front of the class.

However, there were some differences between the previous researches and this research. Hence, this research was still worth to be done. First, dealing with the subject of the research, Donahoo and Barnett used the elementary grade 6 and 5 students in implementing graphic organizer in writing class and Mulyaningsih implemented the strategy to the fifth grade of SD Berkat, Surabaya. Meanwhile, the researcher implemented the strategy to teen learners who were still in Senior High School; at MANU Buntet Pesantren Cirebon because the researcher found the problem and he believed that the strategy would also work for senior high school students.

\section{Sentence Combining Strategy}

Sentence combining has been found to be one of the most effective instructional methods for improving syntactic complexity in writing. In several reviews of the extant literature, sentence combining has been shown to be consistently more effective in improving writing scores than other grammatical approaches, including teaching parts of speech, sentence diagramming, or instruction in transformational grammar rules (Andrews et al., 2006). 
Komolafe (2010: 531) stated that the definition of sentence combining is taking two or more sentence to combine them into different meaningful sentences. She added that the strategies of sentence combination helps students not only know sentence structure but also understand sentence pattern, and even the meaning of the article.

Study related to the application of sentence combining has been conducted by Hudson (2000). He conducted an analysis of 13 previous reviews and 28 additional studies and concluded that the evidence for the efficacy of using sentence combining to improve writing skills was much stronger than commonly supposed. Her analysis was consistent with others showing that traditional grammar teaching is ineffective but sentence combining does result in gains. He added that one way to use sentence combining is as a prompt for more extended writing. In the 1980s, when SC was more prevalent in classroom instruction, some critics charged that its practices didn't allow students to do their own writing that it only had them writing exercises.

Besides, Wyse (2001) came to a similar conclusion following a review of 15 studies, stating that sentence combining is the one method that was beneficial for fostering syntactic maturity in writing. It is a good starter activity: take two sentences and see how many ways the class can find for combining them into a single sentence. Something else you may not know is that it's a guaranteed route to better writing. Start from 1986, there were some research projects on the effects of sentence combining, and reported impressive results.

In short, using a variety of sentence combining methods will enhance students' writing as well by providing a mixture of sentence types and thereby keep the reader from becoming bored.

Here are the sample of using sentence combining strategy in writing:

First Step (Listing some sentences):

- Jury trials are a fundamental civil liberty.

- Juries make legal decisions.

- Those decisions are given to a judge.

- In a bench trial, all decisions are made by judges.

- The system is used only in UK and US.

Second Step (Combining the Sentences):

A jury trial is a legal proceeding where a jury makes decisions. This system is fundamental civil right in the UK and the US, but not in other countries.

\section{Hortatory Exposition}

Nowadays, the English language material adopts the genre-based approach which is considered to be easier, simpler and clearer in terms of the variation of the text. In this approach texts are divided into two which are literary and factual (Anderson, 2003:3). Included in literary text types are narrative, poetry and drama, while factual text types consist of recount, explanation, discussion, information report, exposition, procedure and response. In exposition text type, Anderson and Anderson (2003:1) defines it as a piece of text that presents one side of issue, aiming at persuading someone to believe something.

According to Hartono (2005:7), hortatory exposition text is a factual text used to put forward a point of view, or argument/ recommendation. Meanwhile, Gerrot and Wignel (1994:209) state that hortatory exposition text is a text which represents the 
attempt of the writer to persuade the reader or the listener that something should or should not be the case.

Furthermore, Housden (2008:18) explains that expository text exposes the authors' point of view; it may also be called an argumentative or a persuasive text. The words persuasion and argument are often used interchangeably. Yet, there are some differences that can be noticed. First, it can be seen from the objective and the concluding sentence. Argumentative text aims to convince the reader to believe on writer's point of view by providing a concept, idea or opinion about a problem while persuasive text is aimed to influence reader to do something. Second, after moving from general information in the body, the conclusion returns to the thesis and restates supporting points. While argumentative writing must confirm the evidence that proves the thesis statement, in persuasion, the conclusion addresses the writer's intention and the closing remark may call for action.

In order to encourage students to write hortatory exposition text clearly, students need to be able to write the ideas of a text, vocabulary, word choice, and grammatical pattern. However, many students had difficulties in writing hortatory exposition text, for example in developing and organizing ideas. Ideas in writing are important, whether it leads the students in their writing. With a lack of ideas by the students, they will get stuck what to write in their writing. In addition, the students thought that writing hortatory exposition text was difficult since they did not know their mistake in their writing.

To overcome students' writing, the teacher can use several strategies in order to help students' writing in the classroom. In this research, the researcher used one of the techniques that the writer assumed can overcome students' problem in constructing, arranging, developing and organizing their ideas through tree diagram technique. Tree diagram technique is an outlining technique which can be used to improve the organization of the students' writing.

The social function of hortatory exposition text is to persuade the readers or listeners that something should or should not be the case (Hartono, 2005:6). Meanwhile, its schematic structure is the distinctive beginning, middle-end structure of a genre (i.e. the stages accomplishing a genre's social purpose, the stages may be either obligatory (always present) or optional (present only under certain condition). Hortatory Exposition text has three schematic structures; those are thesis, arguments, reiteration/summing up (Hartono, 2005:7). Whilst, Gerrot and Wignell (1995:92) in making sense of functional grammar, state that generic structures of hortatory exposition are:

1) Thesis

Thesis is a statement or theory supported by arguments long piece of writing or a subject.

Position: it introduces topic and indicates writer's position. Preview: outlines the main arguments to be presented.

2) Arguments

Argument is a connected series of series of statements or prepositions, some of which are intended to provide support, justification or evidence for the truth of another statement or preposition. Arguments consist of one or more promises are those statements that are taken to provide the support or evidence, the conclusion is that which the promises allegedly support. Argument gives reasons for concern to recommendation. Point: restates main argument outlined in preview. 
3) Recommendation

Recommendation is a praising or commend about some phenomena. Recommendation states what ought or not ought to happen and restates writer's position.

Thus, it is clear that the schematic structures of the hortatory exposition text are thesis, arguments, and recommendation.

Language feature is the kind of language which distinguishes the genre from other. A genre is characterized by the use of certain language features (Macken, 1991)

According to Gerrot and Wignell (1994) the language features of hortatory exposition text are:

1) Focus on generic human and nonhuman participants. Generic human participant means a human participant constructed by grammar as having a general identifiable referent in the context.

2) Generic non-human participant means a non-human participant constructed by grammar as having a general identifiable referent in the context.

3) Uses of mental processes, material processes, relational processes

Mental processes are ones of sensing: feeling, thinking, perceiving. Mental process clauses normally have at least one participant representing the one who thinks, sees, likes, and wants and so on. It explains what the writer's opinion about the issues. E.g. think, believe, and so on.

Material processes are processes of material doing which express the notion that some entity physically does something or physical action. Material processes also defined as processes of doing and happening and the actor is the key participants. E.g. construct, can go, and attend, and so on.

Relational processes involve states of being including having. Relational processes are concerned with being, processing or becoming. It also explains what it should be. E.g. can keep, don't, will be, and so on.

4) Use simple present tense

Present tense is used to express habitual or everyday activity. It indicates a situation that exists right now, at the moment speaking. It shows that the things are true in general, or happen sometimes or all the time.

5) Use of modality

Modality is commonly used in argument writings to show certainty of conclusion. E.g. might, can, will.

Thus, it is clear that the language features of the hortatory exposition text are: focus on generic human and non-human participants; use of mental processes, material processes, relational processes; and use of simple present tense.

\section{Students' Interest in Writing}

We know that teachers have very little control over individual interest. What teachers do have control over is situational interest since this type of interest is linked to the learning environment. If teachers understand what stimulates interest, then they can play a more active role in the development of students' academic interest.

Hidi (1990: 54) argued that interest is central in determining the ways in which we select and process certain types of information in preference to others. Dewey identified three psychological components: (1) interest has an active quality to it, an individual "takes" interest; (2) interest is objective in that it is incorporated in an object 
of regard; and (3) interest is personal in that an individual is emotionally invested in the outcome of its interest.

In writing, interest also plays an important role on the students' progress. Hidi and Renninger's review of the interest research provided the structure for identification and analysis of student interest for writing. They identified four phases in the development of student interest based on this review: only a triggered situational interest (Phase 1), a maintained situational interest (Phase 2), an emerging individual interest (Phase 3), and a well-developed individual interest (Phase 4). They reported that students' interest does develop and deepen if they are provided with support by others, such as teachers. They also noted that, if interest is supported to develop, students have increased attention, set and meet goals for themselves, and are more effective in their use of learning strategies.

In this study, each student's current phase of interest is identified based on his responses to a questionnaire that assessed knowledge of, value for, and feelings about writing. Students are also asked about their feelings of self-efficacy for writing, effort as writers, feedback preferences, and involvement with writing both in and out of the classroom. A sample of 40 students, who are selected based on phase of interest, gender, and school year, also participated in in-depth, structured interviews. Data from questionnaires and interviews are summarized to describe shared characteristics of students in each phase of interest for writing. This information should help teachers of writing recognize these traits in their students and begin to identify their current phases of interest for writing.

\section{METHOD}

In this study, this experimental research is aimed at observing whether there is an interaction between teaching strategy and writing skill viewed from students' interest. The technique used in this experimental research is by comparing the experimental group using graphic organizer to control group using sentence combining as a teaching strategy in writing. Each group is divided into two different interests (high and low). This research involves three kinds of variables namely independent variables (teaching strategy), dependent variable (writing skill), and moderator variable (students' interest). The research design used for the research is factorial design $2 \times 2$ by technique of multifactor analysis of variance (ANOVA).

This study was conducted at the eleventh graders of MANU Buntet Pesantren Cirebon in the academic year of 2015/2016. In this research, the target population of this study is all of the eleventh graders of MANU Buntet Pesantren Cirebon in the academic year 2015/2016. The total numbers of the population are 315 students divided into 8 classes.

The sample of this research is two classes of eleventh graders of MANU Buntet Pesantren Cirebon in the academic year of 2015/2016. The two classes are XI IPA 1 and XI IPA 2 which have 40 students in each class. Two classes above are divided into two group experimental group I and experimental group II. Class of XI IPA 1 was as experimental group and XI IPA 2 as control group.

This research involves three kinds of variables, they were: Independent variable: Graphic Organizer and Sentence Combining Strategy Dependent variable: Writing skill focuses on Writing Hortatory Exposition Text Moderator variable: Students' Interest. 


\section{Research Instrument}

There were two instruments used in this research: test, and observation sheet.

\begin{tabular}{|c|c|c|c|}
\hline No & Instruments & Variables to Measure & Function \\
\hline 1 & Questionnaire & Students' interest & To divide samples \\
\hline 2 & Writing Test & $\begin{array}{l}\text { Students' writing skill before } \\
\text { and after treatment. }\end{array}$ & $\begin{array}{l}\text { To measure the students } \\
\text { achievement. }\end{array}$ \\
\hline 3 & Observation & $\begin{array}{l}\text { Students' activities in } \\
\text { classroom towards learning } \\
\text { instruction. }\end{array}$ & $\begin{array}{l}\text { As the follow up activities } \\
\text { to support the result of the } \\
\text { study. }\end{array}$ \\
\hline
\end{tabular}

Table 1 Research Instruments and Variables to Measure

\section{Procedure of the Study}

The research procedures are draw below:

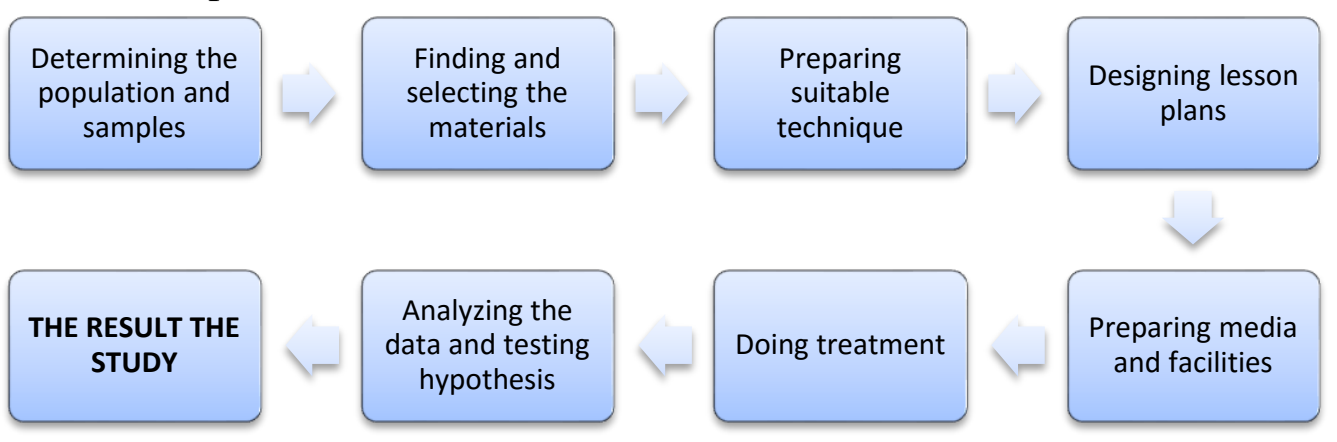

Figure 2 Research Procedures

The experiment was set up according to a pre-test/post-test control group design. Several stages were implemented to accomplish the purpose of this study. First, before the start of the course, the teacher and the researcher spend one week to discuss the overall experimental processes. Second, questionnaire was administered to both group to select the group of high interest and the low one. Pre-test was administered to ensure that prior to the experiment; all groups achieve the same writing task.

Third, the experimental group (both high and low interest) participated in the graphic organizer teaching treatment. The teacher first explains what graphic organizer is, why it is useful for writing, and how to use it. And the second, he spends few hours training students to try it. In different meeting, the students were given the same task as in pre-test.

In the control group (both high and low interest), the teacher gave an introductory lesson that includes the objectives of the lesson and how to proceed, and then taught from the textbook using normal instruction with sentence combining strategy. In different meeting, the students were given the same task as in pre-test also. At the end of the experiment, the teacher then corrected students' work. And all results were counted using formula by the researcher.

The technique of collecting data in this research used test. Test was used to collect data of students' writing skill. The writer evaluated the writing test through some aspects, such as: content, organization, vocabulary, language use (grammar), and mechanics. In order to know the level of students' interest, the students are given questionnaire. 
The techniques to analyze the data of this study are descriptive and inferential analysis. The detail formulation of descriptive analysis (mean, mode, median and standard deviation) will be elaborated below.

a. Mean of the data

b. Mode of the data

$$
\bar{X}=\frac{\sum f i X i}{n}
$$

c. Median of the data

$$
M o=L+i\left(\frac{f_{1}}{f_{1}+f_{2}}\right)
$$

$$
M e=L+i\left(\frac{\frac{n}{2}-c f b}{f w}\right)
$$

d. Standard Deviation of the data

$$
s=\sqrt{\frac{\sum f_{i} X_{i}^{2}-\frac{\left(f_{i} X_{i}\right)^{2}}{n}}{n-1}}
$$

Inferential analysis used in this research related to the design of the research is multifactor analysis of variance (ANOVA). This kind of test was used to find out whether the difference between them is significant or not.

Normality and homogeneity test must be conducted previously before the ANOVA test. Normality test is conducted in order to know whether the sample distributes normally or not, while homogeneity test is aimed at knowing whether the data are homogeneous or not. Liliefors test is used to examine the normality test. Meanwhile, Barlet test is used to examine the homogeneity test.

\section{Result of Normality Test}

After computing the pretest scores obtained by the experimental and control group, the researcher found that the probability (Asimp. Sig) of the experimental group were 0.181 and 0.093 . And the control groups were 0.066 and 0.101 which were higher than the level of significance (0.05). It means that the null hypothesis was accepted or the scores of the experimental and control group are normally distributed.

\section{Result of Homogeneity Test}

The result shows that with the degree of freedom (df) 3 for $d f$ numerator and 56 for $d f$ denumerator; and the level of significant 0.05 compared to the value of $F$ table, the value of $F$ observeis lower ( for experimental group and for control group). This result shows that the null hypotheses $(\mathrm{Ho})$ is accepted. Thus, it can be assumed that the variances of the experimental and control groups are homogeneous.

\section{Result of Writing Test}

The purpose of testing of hypothesis in this section is to find out whether there is a significant difference between the pretest and the posttest scores in the experimental group. According to Brown (1988), there are two possible hypotheses. They are:

Ho : $\mu 1-\mu 2$ 
There is no any significant difference between the means of the pretest and posttest scores.

Hi : $\mu 1>\mu 2$

The mean of the post-test score is higher than that of the pretest one.

Based on SPPS output above, we got Sig. $(2-$ tailed $)=0.000<0.05$, with $t_{\text {count }}=$ 14.270 and $t_{\text {tabel }}=2.575$, because $t_{\text {count }}>t_{\text {table }}(14.270>2.575)$, so if Ho rejected and Ha accepted, it means that there is a significant differences between pre-test and post test score or there is positive effect of graphic organizer on high interest students in writing hortatory exposition text.

Therefore, it was concluded that there was a significant difference between the pretest and posttest scores in the experimental group with high interest in which the post-test score is higher than pretest score. This concluded that the use of graphic organizer has helped the learners of the high interest students in experimental class to obtain higher and more significant scores in writing hortatory exposition text.

\section{FINDINGS and DISCUSSIONS}

This section concerns on the discussion of the research findings in relation to the problems on how to improve and develop high and low interest students in writing hortatory exposition by giving such kind of training on applying graphic organizer. The findings are further elaborated in accordance with the research problems which cover the application of graphic organizer in experimental group. The application was conducted for eight meetings in which one meeting for pretest and one meeting for posttest.

The first result based on the data analysis that graphic organizer is effective on high interest students in writing hortatory text. It was shown from the result of ANOVA test that $\mathrm{Ho}$ is rejected and $\mathrm{Ha}$ is accepted. It is mean that there is a significant difference between pre-test and post test score or there is positive effect of graphic organizer is effective on high interest students in writing hortatory text.

The second conclusion of low interest students taught by graphic organizer shows that Ho is rejected and ha is accepted. It means that there is a significant difference between pre-test and post-test or there is positive effect of graphic organizer on low interest students in writing hortatory exposition text.

The third conclusion shows that the statistical calculation of the students who have high interest taught by sentence combining strategy shows a significant difference. Ho is rejected and ha is accepted. It means that there is a significant difference between pre-test and post-test or there is positive effect of sentence combining strategy on high interest students in writing hortatory exposition text.

The forth conclusion from the data analysis from ANOVA shows that Ho is accepted and $\mathrm{Ha}$ is rejected, it means that there is no significant difference between pretest and post-test or there is no effect of sentence combining strategy on low interest students in writing hortatory exposition text.

The fifth, there is significant difference between the score of experimental group and control group. It shows that graphic organizer is more effective than sentence combining strategy on the high and low students in writing hortatory exposition text.

The last, there is an interaction between teaching strategy and students' interest in writing hortatory exposition text. The interaction happened because both strategies gave affection on students writing. Despite, the use of graphic organizer shows more effect than sentence combining strategy. Students taught by using graphic organizer 
have better Writing abilities than those taught by using sentence combining for the eleventh graders of MANU Buntet Pesantren Cirebon in the academic year of $2015 / 2016$.

In addition, it showed that by implementing the graphic organizer in process writing students could solve the problem in writing hortatory exposition text. This finding was also found by Mulyaningsih (2010), Antoni et al. (2004) in Cahyono and Widiati (2011).

In this case, the role of the teachers is very important in leading students' intention in learning. If the teachers focus his activity on how to write a text by using certain strategy, the students also learn how to write the text using the strategy introduced by the teachers. In addition, they regarded it very helpful for them in term of developing their writing skill. Having schemata of the text, the students find the strategy very helpful in terms of efficiency and effectiveness in understanding writing the text accurately. Once the students enjoy applying certain strategy, a good impact to their achievement will be attained.

Hence, a challenge regarding the mastery of vocabulary and grammar should be taken into consideration by the students in order to be able to develop their writing. In addition, teachers should also be focused on providing good guidance for the students who lack vocabularies and background concepts in relation to write the text. Moreover, teachers should also be creative in creating text that are relevant to students' interest and their experiences based on the various strategies as proposed in interactive strategy. It can further be said that good commitment and careful implementation that fulfill the requirements suggested in graphic organizer influence on the success of the teaching writing of hortatory exposition texts. This means that the strategy can also be implemented in other schools in which teachers should be knowledgeable of the concept of graphic organizer strategy and implement it well. It proves that teachers can be open and ready to adopt and adapt the strategy which is very beneficial for the improvement of the students writing skill.

\section{CONCLUSION}

The findings of this study indicate that graphic organizer is more effective than the sentence combining strategy. It can be seen from the results of both scores in the experimental class that the scores of the post-test have significantly different comparing to the post-test scores in the control group. The result also shows that by implementing the graphic organizer in process writing, students could solve the problem in writing hortatory exposition texts.

In addition, for teen learners graphic organizers facilitate the integration of longterm memory and new learning. Teen learners generally have more background knowledge, and graphic organizers bridge what teen learners already know with what they are learning. Here, graphic organizers actually trigger long-term memory and promote synthesis with new information (Materna, 2007, as cited in Mcknight, 2010:2).

For further research, it is suggested that, as this research only employed factorial design which involved experimental and control groups, further studies employ true experimental design in which the subjects are randomly selected, so both external and internal factors that might influence the students' achievement can be controlled well. Second, since this study only carried out in one of Madrasah Aliyah schools, it is useful for more research to be conducted on a bigger scale. 


\section{REFERENCES}

Alnufaie, M., \& Grenfell, M. (2012). EFL students' writing strategies in Saudi Arabian ESP writing classes: Perspectives on learning strategies in self-access language learning. Studies in Self-Access Learning Journal, 3(4), 407-422.

Anderson, M. \& Anderson, K. (2003). Text type in English 3. South Yarra: Macmillan Education.

Andrews, R., Torgerson, C., Beverton, S., Freeman, A., Locke, T., Law, G., et al. (2006). The effect of grammar teaching on writing development. British Educational Research Journal, 32, 39-55.

Arikunto, Suharsimi. (2002). Prosedur Penelitian. Jakarta: Rineka Cipta.

Barnett, K.P. 2007.Graphic Organizers' Effectiveness in Teaching Comprehension in Reading and Social studies. Alabama. Accessed on $15^{\text {th }}$ April, 2012 from www. The University of Alabama.html.

Baxendell, B.W. (2003).Consistent, coherent, creative the 3 c's of graphic organizers. Teaching Exceptional Children, 35(3), 46-53.

Bromley, K., Irwin-Devitis, L., \& Modlo, M. (1995). Graphic organizers: visual strategies for active learning. New York: scholastic professional books.

Brown, H.D. (2001).Teaching by principle: An interactive approach to language pedagogy (2nd Ed). Wesley: Longman.

Cahyono and Widiati.(2011).The Teaching of English as a Foreign Language in Indonesia. Malang: State University of Malang press.

Donahoo, L. (2009). The Impact of Using Graphic Organizer on Written Language with Sixth Grade Resource Student. Presented to the Shawnee mission

Ellis, E., \& Howard, P. (2005). Graphic organizers: Power tools for teaching students with learning disabilities. Graphic Organizers and Learning Disabilities 1, 1-5. KS: Edge Enterprises

Ellis, Farmer, \& Newman, (2005). Big Ideas about Teaching Big Ideas. Sage Journals. Vol 38, Issue 1, 2005

Gerrot and Wignell, L. (1994). Making Sense of Functional Grammar. New South Walles: Gerd Stabler.

Harmer, Jeremy. (1999).The Practice of English Language Teaching 3rd Edition. Cambridge UK: Longman.

Hartman. (2002). Graphic Organizers as a Teaching Strategy. City College of New York. Accessed on 17th October 2012from http/www.awresrchpprpage.htm.

Hartono, R. (2005). Genre of Texts. Semarang: Semarang State University

Hidi, S. (1990). Interest and its contribution as a mental resource for learning.

Housden, Elli. (2008). Senior Text Types: A Writing Guide for Students. Queensland: FarrBooks

Hudson, R. (2000). Grammar teaching and writing skills: the research evidence. London: Dept. of Phonetics and Linguistics, UCL, Gower Str.

Hyland, K. (2008). Writing Theories and Writing Pedagogies. Indonesian Journal of English Language Teaching, 4(2), 91-110.

Hyland, Ken. (2009). Teaching and Researching Writing. London: Pearson Education Limited.

Katayama, Andrew, D, and Daniel H. Robinson. (2000). Getting students 'Partially' involved in Note - Taking Using Graphic Organizers. Journal of Experimental 
Education68 (2) 115-119. Accessed on February 13 ${ }^{\text {th }}, 2012$ from www.heldref.org.

Komolafe, A. T., \& Yara, P. O. (2010). Sentence Combining Strategy and Primary School Pupils Achievement in Written English in Ibadan. Nigeria: European Journal of Scientific Research, 40(4), 531-539.

Mcknight, K.(2010). The Teacher's Big Book of Graphic Organizers, San- Francisco: Jossey-Bass.

Morin, A. (2012). Children parenting about: graphic organizers. http:www. childparentingabout.com

$\mathrm{Mu}, \mathrm{C} .$, \& Carrington, S. (2007). An investigation of three chinese students' english writing strategies. The Electronic Journal for English as a Second Language 11(1). Retrieved October 2, 2012, from http://www.tesl-ej.org/wordpress/.

Mulyaningsih, S. (2010). Using Graphic Organizers to Improve Students' English Writing Skill in The Process of Communicating At the Fifth Grade Elementary Chool of Sekolah Citra Berkat Surabaya. Malang: The State University of Malang.

Nunan, D. (1999). Second Language Teaching and Learning. USA: Heinle \& Heinle Publishers.

Review of Educational Research, 60(4), 549-571.

Review of Educational Research, 60(4), 549-571.

Richard and Renandya. (2002). Methodology in Language Teaching: An Anthology of Current Practice. Cambridge University Press.

Trang \& Hoa. (2008). Students Writing Processes, Perceptions, Problems, and Strategies in Writing Academic essays in L2: A Case Study. VNU Journal of Science, 184-197.

Tuzlukova, V., Al-Seyabi, F., Al-Rawahi, A. \& Al-Owasi, A. (2014). Reading in the English Foundation Programme Class: Omani students' attitudes, thoughts and self-perceived practices. In: Emery, H. \& Moore, N. (Eds). Teaching, learning and researching reading in EFL. TESOL Arabia Publications, 70-87.

Wyse, D. (2001). Grammar for Writing? A Critical Review of Empirical Evidence. London: British Journal of Educational Studies. 